\title{
Michael Allan
}

In the Shadow of World Literature: Sites of Reading in Colonial Egypt. Part of the series Translation/Translation, ed. Emily Apter. Princeton: Princeton University Press, 2016. 200 pages. Paperback \$35.oo.

Cairo writes, Beirut publishes, Iraq reads. So goes the infamous adage on the history of literary modernity in the Middle East. The pithy phrase speaks to some of the material realities of publishing within the region, while also, (partially) tracing the flows of intellectual capital and attendant literary forms. And yet, the adage conceals as much as it reveals. Composed in the present tense, it fails to account for the historical situatedness of such monumental claims. In its attempt to encompass the processes of literary production, distribution, circulation, and reception, the adage neglects certain very basic, yet crucial, questions. For example, what is being written? What makes publication possible? And, what does it mean to read?

These are the kinds of questions that Michael Allan compels us to ask, not only of the disciplines of comparative and world literatures, but more crucially, about the assumptions, tastes, sensibilities, and embodied practices that constitute our own reading practices as literary scholars and critics. Allan's incisive In the Shadow of World Literature: Sites of Reading in Colonial Egypt mobilizes reading as a framework for interrogating the now ubiquitous field of world literature. Combining literary history and critical theory, he turns to the context of nineteenth- and twentieth-century Egypt "as a paradigmatic site from which to consider literary publics, textual cultures, and the history of reading" (3). Dispelling the center/periphery world-systems theory persuasion of postcolonial criticism, Egypt instead functions as a site from which to (re)theorize literacy, reading, and literature within the world republic of letters. In so doing, Allan's highly interdisciplinary study at once draws upon and contributes to debates within postcolonial theory, secular criticism, the anthropology of Islam, and historicist philology.

Organized around a series of critical terms central to the theorization of world literature, six chapters trace the conceptual categories of (1) world; (2) translation; (3) education; (4) literature; (5) critique; and (6) intellectuals. In each chapter, Allan meticulously curates a series of encounters in which the 'historical' and the 'literary' meet around shared imaginings of what and how one reads, as well as questions of who can read and what constitutes literacy. For example, he pairs the epistolary correspondence between André Gide and Ṭāhā Ḥusayn alongside a fictional epistolary exchange between two intellectuals in Husayn's 1935 novella Adīb in the chapter on 'intellectuals;' the 1882 Lewis affair, during which a professor was reprimanded for citing Darwin in 
a commencement address at the Syrian Protestant College in Beirut, is read alongside a fictional scene in Najīb Maḥuzż's novel Qaṣr al-Shawq (Palace of Desire), in which a young scholar's family is morally outraged when he publishes an article on Darwin in the chapter on 'critique.' The staging of these pairings allows for critical readings of these encounters that surpass the sum of their constitutive parts. In the process, the titular concepts are defamiliarized.

Across these chapters, there is a greater argument at play regarding how reading is ascribed value within the context of the world republic of letters. Allan subsequently invokes two critical genealogies. The first entails theorizations of world literature put forth in David Damrosch's What is World Literature (2003) and Pascale Casanova's The World Republic of Letters (2004). Indeed, In the Shadow of World Literature is part of Emily Apter's influential series on Translation/Transnation in which Damrosch's study was initially published. The second axis pertains to the fraught question of secularism, particularly within Edward Said's theory of secular criticism introduced in his 1983 The World, the Text, and the Critic. Allan's engagement with secular criticism builds upon the work of Charles Taylor and Michael Warner, as well as studies in the anthropology of Islam by Talal Asad, Saba Mahmood, and Charles Hirschkind. He calls into question the false binaries of secular/religious, modern/traditional, cosmopolitan/provincial, educated/uneducated, and literate/illiterate that betray the modernization narrative belying discussions of world literature.

In many ways, the formal construction of In the Shadow of World Literature mirrors Allan's broader argument. The book's anti-teleological organization around conceptual terms and textual encounters, rather than distinct historical moments, resists the periodization that normally undergirds theorizations of literary modernity. Similarly, Allan's analytic methodology reanimates formalist critical practices, alongside extra-textual considerations that are often occluded in the process of entextualization. Notably, he "suspends an investment in close reading," approaching world literature instead as "a problem of reading and reception" that turns to "the world in which the text accrues meaning" (133-4). Allan thus renders legible the "semiotic and phenomenological differences between how texts are lived, embodied, and experienced" that are often leveled out in the service of world literary discourse. In so doing, he exposes the "provincial literary world" behind the seeming cosmopolitanism of world literature (116).

To read world literature "less as an accumulation of texts from across different literary traditions than as the globalization of literary hermeneutics," one must turn at once to material institutional considerations (universities, libraries, publishing houses, curricula), as well as their attendant practices (canonization, pedagogy, taste, opinion, sensibilities, critique) (41). We are reminded that reading is a cultivated practice tied to institutions equipped 
with their own histories, persuasions, and interests. Within this configuration, 'literature' and the 'world' exist not as fixed ontological realities, but rather, as co-constitutional figurations of the world literary imagination. Reading emerges as a disciplined practice inseparable from the disciplinary formations that determine the parameters of what counts as literature and how literature matters - to borrow Allan's pivotal term.

In the Shadow of World Literature reveals the operational logic of literary modernity beyond the siloed discourse of the world republic of letters. Purporting to transgress national or linguistic borders, this republic universalizes specific literary sensibilities by delimiting who can read and how, as well as what counts as literature. Allan thus shifts attention from the site of writing (national literature, national language, or ethnic identity) to sites of reading, as well as the conditions that make reading of a particular kind possible. This is not, however, reception theory, nor a study of the transnational circulation of literary production, literary forms, or literary readers. Rather, it is an interrogation of how reading publics are forged, as well as who or what is left out in the disciplining of literature and the acts of reading that are ascribed value, legibility, or visibility.

What kinds of reading practices come to matter then? The concept of adab is one means through which In the Shadow of World Literature traces the relationship between reading, secularism, and literature. First appearing in the 8th century, for much of its history adab encompassed a broad range of textual materials and genres, in addition to carrying the valence of ethical, moral, as well as intellectual education and refinement. Allan analyzes its significatory evolution in relation to institutional transformations within Egyptian education, pedagogy, and literacy. He situates adab's codification as literature within "the rise of literary study as a modern discipline" in fin-de-siècle Egypt (15). The concept of $a d a b$ offers an alternative genealogy for understanding literary practices, tastes, and forms, that troubles the seeming universality-across both historical time and geography — of literature proper. Methodologically, it speaks to Allan's commitment to work from within the conceptual language of a specific historical moment, in order to problematize critical concerns that normally fall within the purview of a Euro-American theoretical canon.

Foregrounding the institutional forces that diluted adab's inherent polysemy serves another function, however. It directs our attention to the qualities of reading that were effaced in adab's conversion into literature. Specifically, the uncoupling of reading from its ethical or embodied dimensions privileges a secularized understanding of critical reading that disavows other modes of literacy, reading practices, or textual forms. Allan joins Asad, Mahmood, Taylor, and Warner, in arguing that "secularism actively defines religion, universalizes liberal notions of rights, and redefines the meaning of personhood." 
These scholars remind us that the privatization of a series of beliefs, practices, experiences, and discourses under the transcendental category of 'religion' is a relatively recent fiction of the secular imagination. Put otherwise, "secularism is not the neutral detachment of religion from matters of the state, but the active involvement of the state in defining and delimiting what constitutes religion" (10). Within the world republic of letters, the 'world' and 'literature' similarly codify modes of reading tied to the universalization of secular modes of knowledge production and subjectivity.

Reframing literary reading as a nexus of embodied practices, habits, and tastes, directs us away from generic understandings of literature as a mere taxonomy of texts-hence Allan's invocation of René Wellek and the formalist concept of literariness. If the terms of literariness shift according to the particularities of time and place, then "defining what literature or adab is implies a command about how to read" at a given moment (77). Allan subsequently invites us "to consider how secular criticism defines religion as seemingly inimical to critical analysis," and to "begin to ask how secularism frames investments in particular definitions of what constitutes literary reading and sanctions ignorance about modes of textuality, dissent, and discussion within traditions deemed religious" (137). In the Shadow of World Literature thus examines various moments in which pedagogical models associated with Qur'ānic schools generate types of literacy that are illegible to a secular understanding of critical reading. These individuals are interpellated as 'traditional,' 'uneducated,' or 'illiterate,' because their education entails embodied practices that abide by their own ethical and aesthetic standards - such as rote recitation, memorization, and citation. In the context of colonial Egypt, this disjuncture resulted in a pedagogical shift from tarbiyah - meaning cultivation or rearing, generally with the implication of "the students' moral development through education" - to ta'lim, signaling the colonial model of education that entailed "a corpus of material to be transmitted to the student" (57). The humanist discourse of secular liberalism thus privileges educational models that cultivate subjects governable within a modern (secular) state apparatus. This "inherent political education" exists within its own hermetic "moral universe of modernization," in which any critiques of/outside the system are deemed unthinkable (72-3).

What, then, are the implications of Allan's study for comparatists and literary scholars, particularly those working on 'non-western' literatures? In the Shadow of World Literature suggests that the act of comparison relies upon the creation of stable objects, categories, or contexts of comparison-largely by flattening "phenomenological differences between interpretive lifeworlds" (38). In light of the book's broader argument about the secular imagination that underwrites the world literary system, it stands to reason that comparative cultural 
analysis is itself a kind of secularizing practice. And while we cannot necessarily think ourselves outside of a secular cosmological order-literary or otherwise - we can at the very least interrogate its borders and limitations. If, as Allan contends, "literature is not the domain of a national canon, a particular author, or a specific language, but instead delimits a sensibility closely aligned with presumptions about what it means to be modern, educated, and critical," to do so we must be attentive to the margins of what constitutes both a literary object, and an educated reader/modern subject (61).

One might wonder why these margins are so canonical in Allan's study, which encompasses towering figures of the Egyptian literary establishment such as Ṭāhā Ḥusayn and Najīb Maḥfūz, alongside renowned writers from the Levant, such as Jirjī Zaydān and Ḥaydar Ḥaydar. The book certainly reorients this canon, bringing to the fore extra-textual controversies, elisions, footnotes, and marginalia, that keep us on the fringes of the literary. In the process, we are left to reflect upon questions of mediation, in which "representation is inseparable from the world certain representational regimes make knowable" (97). Canonization, particularly within the context of the world republic of letters, is thus instrumental to the inner workings of such regimes, and more crucially, the forms of knowledge production that they champion.

In the Shadow of World Literature's critical self-positioning of its own sites of reading (Us academia, comparative literature, the Egyptian colonial archive), alongside consistent signposting for the book's broader argument, are a refreshing departure from the stylistic tendencies of most first monographs. The elegant restraint of the prose and lack of reliance upon technical jargon further make the book a valuable resource for the classroom. The call to critically reflect upon our own subject positions and investments as readers and critics promises more than a mere understanding of "the conditions of belonging to the world republic of letters" (133). The book ends on a somewhat wistful, if not cautiously optimistic note, calling upon us to learn how to read anew. For Allan, this means tending to the fraught relationship between word and world, ontology and epistemology, as well as literature and literary reader, that condition our own sites of reading. In bringing out of the shadows illegible readers, texts, and hermeneutical practices, In the Shadow of World Literature suggests that our best hope is to imagine a world of literature as unfamiliar as the world which we inhabit; or, to borrow Allan's words, "to appreciate the entire world as a place of exile" (140).

\section{Hoda El Shakry}

Pennsylvania State University

hze1o7@psu.edu 